\title{
ANALISIS KEMAMPUAN KOMUNIKASI MATEMATIS SISWA PADA MODEL PEMBELAJARAN THINKING ALOUD PAIR PROBLEM SOLVING
}

\author{
Khairul Saleh Siregar ${ }^{1}$, Yulita Moliq Rangkuti ${ }^{2}$, Syafari $^{2}$
}

\begin{abstract}
ABSTRAK
Penelitian ini bertujuan untuk mendeskripsikan: (1) tingkat kemampuan komunikasi matematis siswa dengan menggunakan model pembelajaran Thinking Aloud Pair Problem Solving, (2) kesulitan kemampuan komunikasi matematis yang dialami siswa dalam menyelesaikan soal pada model pembelajaran Thinking Aloud Pair Problem Solving. Penelitian ini merupakan penelitian kualitatif dengan pendekatan deskriptif, dimana kemampuan komunikasi matematis merupakan cara penyampaian informasi mengenai ide gagasan matematis melalui simbol-simbol ayau gambar baik lisan atau tulisan. Dari hasil penelitian diperoleh bahwa : (1) tingkat kemampuan komunikasi matematis siswa dengan menggunakan model pembelajaran Thinking Aloud Pair Problem Solving yang berkemampuan sedang memiliki proporsi tertinggi sebesar 32\% kemudian diikuti oleh siswa berkemampuan rendah sebesar $20 \%$ dan terakhir siswa berkemampuan sangat tinggi, tinggi, dan sangat rendah masing-masing sebesar 16\%, (2) kesulitan kemampuan komunikasi matematis siswa, dimana 32\% siswa tidak mengalami kesulitan, 32\% siswa mengalami sedikit kesulitan, $36 \%$ mengalami kesulitan, dimana kesulitan siswa yang terlihat dari aspek indicator kemampuan komunikasi matematis siswa yaitu ekspresi, menggambar, pemahaman matematika.
\end{abstract}

Kata Kunci: Kemampuan Komunikasi Matematis, Thinking Aloud Pair Problem Solving

\section{PENDAHULUAN}

Perkembangan ilmu pengetahuan dan teknologi memegang peranan yang sangat penting dalam kehidupan. Perkembangan ilmu pengetahuan dan teknologi ini tidak terlepas dari konstribusi bidang matematika, karena matematika merupakan ilmu universal yang mendasari perkembangan teknologi modern. Sebagai bagian dari pendidikan, pembelajaran merupakan proses interaksi peserta didik dengan pendidik dan sumber belajar pada suatu lingkungan belajar. Pembelajaran adalah bantuan yang diberikan pendidik agar dapat terjadi proses perolehan ilmu dan pengetahuan, penguasaan kemahiran dan tabiat, serta pembentukan sikap dan kepercayaan para siswa.

Menurut Depdiknas (2006:105) menyatakan bahwa matematika merupakan ilmu universal yang mendasari perkembangan teknologi modren, mempunyai peran penting dalam berbagai dan memajukan daya pikir manusia. Matematika memiliki peranan penting dalam kehidupan sehari-hari. Untuk diketahui bahwa matematika bukan hanya aktivitas penjumlahan, pengurangan, pembagian, dan perkalian karena bermatematika dizaman sekarang harus aplikatif dan sesuai dengan kebutuhan hidup modern. Salah satu perubahan paradigma pembelajaran adalah orientasi yang semula berpusat pada guru beralih berpusat pada murid, metodologi yang semula lebih didominasi ekspositori berganti ke partisipatori dan pendekatan yang semula lebih banyak bersifat tekstual berubah menjadi kontekstual. Semua perubahan tersebut

\footnotetext{
${ }^{1}$ Corresponding Author: Khairul Saleh Siregar

Guru Matematika SMP Swasta Nur Ihsan, Medan, 20222, Indonesia E-mail: khairulsaleh.siregar@gmail.com

${ }^{2}$ Co-Author: Yulita Moliq Rangkuti \& Syafari

Program Studi Pendidikan Matematika Universitas Negeri Medan, Medan, 20221, Indonesia
}

dimaksudkan untuk memperbaiki mutu pendidikan, baik dari segi proses maupun hasil pendidikan (Trianto, 2009:8).

Komunikasi matematika menjadi bagian penting dalam pembelajaran matematika karena melalui komunikasi peserta didik mampu mengorganisasi dan mengonsolidasi berpikir matematisnya, serta mampu mengeskplorasi ide-ide matematika. Hal tersebut sejalan dengan tujuan mata pelajaran matematika yang tertuang dalam Lampiran III Permendikbud No. 58 Tahun 2014 yaitu mengomunikasikan gagasan, penalaran serta mampu menyusun bukti matematika dengan menggunakan kalimat lengkap, simbol, tabel, diagram atau media lain untuk memperjelas keadaan atau masalah. Selain itu, komunikasi matematika menjadi penting karena merupakan bahasa simbol yang terlukis dalam proses simbolisasi dan formulasi yaitu mengubah pernyataan ke dalam bentuk rumus, simbol atau gambar.

Menurut Kartono dan Sunarmi (2015:128) menyebutkan tanpa kemampuan komunikasi matematis maka siswa tidak akan mampu menyampaikan ide/gagasan matematisnya kepada orang lain. Oleh karena itu, dalam pembelajaran matematika kemampuan komunikasi matematis sangat penting untuk dimiliki siswa, guna untuk menyampaikan ide/gagasan matematisnya kepada orang lain sesuai dengan keinginannya.

Kenyataannya di lapangan menunjukkan bahwa siswa tidak memiliki kemampuan komunikasi matematis yang baik. Menurut hasil Trend in Mathematics and Scince Study (TIMSS) pada tahun 2011 menunjukkan bahwa siswa di Indonesia yang memiliki kemampuan komunikasi matematis hanya sebesar $57 \%$ dibandingkan negara lain yang $80 \%$ siswanya sudah memiliki kemampuan komunikasi 
matematis, dimana hal ini menyebabkan Indonesia menempati urutan ke-45 dari 49 negara dengan ratarata yang ditetapkan oleh TIMSS.

Berdasarkan kenyataan di atas kemampuan komunikasi matematis siswa masih rendah dan kenyataan ini juga dialami oleh siswa yang ada di kelas VII-A di SMP Wiraswasta Bt Kuis, dimana pada riset awal siswa dalam menyelesaikan soal siswa tidak dapat menunjukkan jawaban melalui indikator komunikasi matematis. Dan dari 25 orang siswa hanya 8 orang siswa yang mampu menyelesaikan dan tergolong cukup baik, selain itu dilihat dari cara penyelesaian masalah yang dilakukan oleh siswa ternyata siswa masih belum mampu menunjukkan jawabannya melalui indikator komunikasi matematis.

Hal tersebut merupakan suatu fakta yang membuktikan bahwa kemampuan komunkasi matematis di SMP Wiraswasta Bt Kuis masih rendah dikarenakan beberapa hal, antara lain: (a) guru cenderung mendominasi dalam kegiatan belajar mengajar; (b) pembelajaran yang diberikan oleh guru kurang bermakna; (c) pola pembelajaran guru bersifat rutinitas, pada saat mengajar matematika, guru langsung menjelaskan topik yang akan dipelajari.

\section{KAJIAN TEORITIS}

\section{Kemampuan Komunikasi Matematis}

Komunikasi yang dimaksud adalah kemampuan siswa dalam menyampaikan atau menerima gagasan, sehingga terjadi proses belajar. Pada pembelajaran matematika yang berpusat pada siswa, pemberi pesan tidak terbatas dari siswa saja melainkan dapat dilakukan oleh siswa maupun orang lain. Pesan yang dimaksud adalah konsep-konsep matematika, dan cara menyampaikan pesan dapat dilakukan baik melalui lisan maupun tulisan.

Tabel 1. Indikator Kemampuam Komunikasi Matematis

\begin{tabular}{|c|c|}
\hline Aspek & $\begin{array}{l}\text { Indikator Kemampuam } \\
\text { Komunikasi Matematis }\end{array}$ \\
\hline $\begin{array}{l}\text { Ekspresi } \\
\text { matematika }\end{array}$ & $\begin{array}{l}\text { Mengungkapkan ide atau situasi } \\
\text { matematika dari suatu gambar yang } \\
\text { dilengkapi dengan kata-katanya } \\
\text { sendiri secara tertulis. }\end{array}$ \\
\hline $\begin{array}{l}\text { Menggambar } \\
\text { Matematika }\end{array}$ & $\begin{array}{l}\text { Menyatakan suatu situasi dalam } \\
\text { bentuk gambar atau grafik. }\end{array}$ \\
\hline $\begin{array}{l}\text { Pemahaman } \\
\text { Matematika }\end{array}$ & $\begin{array}{l}\text { Mampu menyatakan atau } \\
\text { menjelaskan situasi dalam bentuk } \\
\text { notasi atau simbol matematika atau } \\
\text { model matematika. }\end{array}$ \\
\hline
\end{tabular}

Menurut Suharno, Sulistiawati \& Arifin (2019:169) kemampuan komunikasi matematis adalah kemampuan siswa dalam menyampaikan informasi matematis, ide atau gagasan matematis baik secara lisan maupun tulisan. Menurut Ansari (2009:14) komunikasi merupakan suatu interaksi yang dilakukan orang-orang dalam proses penyampaian pesan melalui pertukaran informasi, ide, keterampilan, dengan menggunakan simbol-simbol, gambar dan sebagainya menghasilkan suatu informasi tertentu dengan tujuan tertentu. Dari uraian di atas dapat disimpulkan bahwa kemampuan komunikasi matematis siswa merupakan cara penyampaian informasi mengenai ide gagasan matematis melalui simbol-simbol atau gambar baik secara lisan dan tulisan. Adapun indikator kemampuan komunikasi matematis dalam penelitian ini disajikan pada Tabel 1 .

\section{Model Thinking Aloud Pair Problem Solving}

Thinking Aloud Pair Problem Solving (TAPPS) dapat diartikan sebagai teknik berpikir keras secara berpasangan dalam penyelesaian masalah. Model TAPPS lebih ditekankan kepada kemampuan penyelesaian masalah (problem solving). Model TAPPS adalah strategi untuk meningkatkan kemampuan penyelesaian masalah melalui penyelidikan dan perluasan verbal.

Dalam TAPPS, setiap pasangan diberi suatu masalah yang harus dipecahkan. Problem solver bertugas memecahkan masalah dan menyampaikan semua gagasan dan pemikirannya selama proses pemecahan masalah kepada listener. Sedangkan listener bertugas mengikuti dan mengoreksi dengan cara mendengarkan seluruh proses yang dilakukan problem solver dalam memecahkan masalah dan memberikan petunjuk pemecahan masalah dengan cara bertanya hal-hal yang berkaitan dengan pemecahan masalah tersebut dan tidak langsung menunjukkan pemecahan masalah yang dimaksud.Adapun prosedur Think Aloud Aloud Pair Problem Solving adalah sebagai berikut :

1. Minta siswa membentuk pasangan dan jelaskan pada mereka peran-peran-peran penyelesaian masalah dan pendengar. Peran penyelesaian masalah adalah membacakan masalah secara lisan dan mengutarakan proses penalaran yang digunakan dalam menyelesaiakan masalah tersebut. Peran pendengar adalah mendorong penyelesaian masalah untuk berpikir secara lisin, dan menggambarkan langkah-langkah penyelesaian masalah tersebut. Pendengar juga dapat mengajukan pertanyaan-pertanyaan klarifikasi dan menawarkan saran-saran, tetatp tetap harus menahan diri untuk menyelesaikan masalah.

2. Minta siswa menyelesaiakan sejumlah masalah,saling berganti peran untuk setiap masalah baru.

3. Kegiatan akan dihentikan apabila siswa telah berhasil menyelesaikan seluruh masalah.

\section{Kesulitan kemampuan komunikasi matematis siswa dialami siswa}

Kesulitan dalam menyelesaikan kemampuan komunikasi matematis berkesinambungan dengan objek matematika. Dalam kesulitan menjelaskan ide atau situasi yang digambarkan dengan kata-katanya sendiri secara tertulis misalnya siswa mengalami kesulitan kemampuan komunikasi matematis dimana siswa belum mampu menjelaskan dan mengungkapkan ide atau situasi dengan kata-katanya sendiri secara tertulis dari suatu wacana, kesulitan menyatakan dan 
mendeskripsikan suatu situasi dengan gambar ke dalam symbol/notasi atau bahasa misalnya siswa mengalami kesulitan prosedur dan kesulitan menyatakan suatu situasi ke dalam model matematis misalnya siswa mengalami kesulitan prinsip, dimana ketidakmampuan siswa menerapkan aturan-aturan atau rumus-rumus matematika. Dan saat memberikan kesimpulan pada jawaban di akhir kurang mampu.

\section{METODE PENELITIAN}

Jenis penelitian yang digunakan dalam penelitian ini adalah penelitian kualitatif. Penelitian kualitatif maksudnya adalah penelitian yang menggambarkan apa adanya tentang sesuatu variabel, gejala, atau tentang suatu keadaan dalam Arikunto (2015:315). Jenis kualitatif artinya jenis penelitian ini bertujuan untuk mendekripsikan kemampuan komunikasi matematis dengan penerapan model pembelajaran Thinking Aloud Pair Problem Solving. Data yang dihasilkan berupa kata-kata atau ucapan-ucapan yang diperoleh dari hasil wawancara dan tulisan atau bilangan yang diperoleh dari hasil wawancara. Penelitian ini telah dilaksanakan di di SMP Wiraswasta Batang Kuis, di kelas VII pada Tahun Ajaran 2020/2021 dengan Subjek yaitu siswa kelas VII-A yang berjumlah 25 siswa. Instrument yang digunakan kualitatif. Sugiyono (2016:222) menjelaskan “dalam penelitian kualitatif, yang menjadi instrumen atau alat penelitian adalah peneliti itu sendiri". Instrumen utama dalam penelitian ini adalah peneliti sendiri, yang berarti kedudukan peneliti merupakan kunci (penentu) dalam penjaringan maupun menganalisis data. Selain peneliti sebagai instrumen utama dalam penelitian dikembangkan instrumen sederhana untuk, mempertajam serta melengkapi data hasil penelitian. Instrumen tersebut antara lain: tes kemampuan komunikasi matematis, dan pedoman wawancara.

\section{Teknik Analisis Data}

Untuk mengukur tingkat kemampuan komunikasi matematis siswa secara individu digunkan rumus sebagai berikut:

Keterangan:

$$
\mathrm{P}=\frac{\mathrm{X}}{\mathrm{Y}} \times 100 \%
$$

$\mathrm{P}=$ Tingkat Kemampuan Komunikasi matematis tiap individu

$\mathrm{X}=$ Skor total yang diperoleh oleh individu

$\mathrm{Y}=$ Skor ideal tiap item

Tabel 2. Tingkat Kemampuan Komunikasi Matematis Siswa

\begin{tabular}{cc}
\hline SKKM (Presentase) & Kategori \\
\hline $90,00 \leq \mathrm{P} \leq 100$ & Sangat tinggi \\
\hline $80,00 \leq \mathrm{P}<90,00$ & Tinggi \\
\hline $65,00 \leq \mathrm{P}<80,00$ & Sedang \\
\hline $55,00 \leq \mathrm{P}<65,00$ & Rendah \\
\hline $\mathrm{P}<55,00$ & Sangat rendah \\
\hline
\end{tabular}

Selanjutnya hasil presentase skor tingkat kemampuan komunikasi matematis siswa dikategorikan kedalam kategori sangat tinggi, tinggi, sedang, rendah, sangat rendah (lihat tabel 2). Kategori ini di konversi dengan menggunakan konversi skor menurut Nurkancana dan Sunarta dalam Sriwahyuni, Amelia \& Maya (2019:20).

\section{HASIL PENELITIAN \\ Deskripsi Tingkat Kemampuan komunikasi Matematis Siswa}

Adapun tingkat kemampuan komunikasi matematis siswa dapat dilihat pada Tabel 3 berikut ini.

Tabel 3. Hasil Tingkat Kemampuan

Komunikasi Matematis Siswa

\begin{tabular}{cccc}
\hline $\begin{array}{c}\text { SKKM } \\
\text { Persentase) }\end{array}$ & $\begin{array}{c}\text { Jumlah } \\
\text { Siswa }\end{array}$ & Persentase & Kriteria \\
\hline $\begin{array}{c}90,00 \leq \mathrm{P} \leq \\
100\end{array}$ & 4 & 16 & $\begin{array}{c}\text { Sangat } \\
\text { tinggi }\end{array}$ \\
\hline $\begin{array}{c}80,00 \leq \mathrm{P}< \\
90,00\end{array}$ & 4 & 16 & Tinggi \\
\hline $\begin{array}{c}65,00 \leq \mathrm{P}< \\
80,00\end{array}$ & 8 & 32 & Sedang \\
\hline $\begin{array}{c}55,00 \leq \mathrm{P}< \\
65,00\end{array}$ & 5 & 20 & Rendah \\
\hline $\mathrm{P}<55,00$ & 4 & 16 & $\begin{array}{c}\text { Sangat } \\
\text { rendah }\end{array}$ \\
\hline
\end{tabular}

Berdasarkan tabel 3 menunjukkan hasil tes kemampuan komunikasi matematis siswa sebanyak 25 siswa. Pada tabel 3 ini hasil kemampuan komunikasi matematis dikategorikan atas lima kategori yaitu sangat tinggi, tinggi, sedang, rendah, dan sangat rendah. Dari hasil tes diperoleh siswa dengan kategori sangat tinggi sebanyak 4 siswa, siswa dengan kategori tinggi sebanyak 4 siswa, siswa dengan kategori sedang sebanyak 8 siswa, siswa dengan kategori rendah sebanyak 5 siswa, dan siswa dengan kategori sangat rendah sebanyak 4 siswa.

Jadi dari 25 siswa tersebut ternyata tingkat kemampuan komunikasi matematis pada siswa berkemampuan "sedang" memiliki proporsi tertinggi sebanyak $32 \%$ berjumlah 8 siswa, kemudian diikuti siswa berkemampuan "rendah" sebanyak 20\% dengan jumlah 5 siswa, dan dilanjut dengan berkemampuan "sangat tinggi", "tinggi" dan "sangat rendah" masingmasing sebanyak $16 \%$ dengan jumlah 4 siswa. Berdasarkan hasil tes yang diberikan untuk mengukur kemampuan komunikasi matematis siswa, dideskripsikan tingkat kemampuan komunikasi matematis siswa pada setiap indikator komunikasi matematis siswa yang diteliti sebagai berikut:

\section{a. Ekspresi Matematika (Indikator 1)}

Pada indikator ini siswa harus mengungkapkan ide atau situasi matematika dari suatu gambar yang dilengkapi dengan kata-katanya sendiri dan menuliskan simbol (notasi) matematika secara tertulis.. Hasil tes kemampuan komunikasi matematis berdasarkan pada indikator ini ditunjukkan pada Tabel 4.

Berdasarkan tabel 4, dapat dilihat tingkat kemampuan siswa pada indikator ekspresi matematika, terdapat 0 siswa dengan kategori sangat tinggi, 2 siswa siswa dengan kategori tinggi, 6 siswa dengan kategori sedang, 11 siswa dengan kategori rendah, dan 6 siswa 
Vol. 14, No. 1, Juni 2021

\begin{abstract}
dengan kategori sangat rendah. Jadi dari 25 siswa tersebut ternyata tingkat kemampuan komunikasi matematis pada indikator ekspresi matematika menyatakan siswa berkemampuan "rendah" memiliki proporsi tertinggi sebanyak $44 \%$ berjumlah 11 siswa, kemudian diikuti siswa berkemampuan "sedang ", "sangat rendah" sebanyak 24\% dengan jumlah 6 siswa, dilanjut dengan berkemampuan "tinggi" sebanyak $8 \%$ dengan jumlah 2 siswa, dan siswa berkamampuan "sangat tinggi" sebanyak 0\% dengan jumlah 0 siswa. Dapat disimpulkan bahwa siswa pada indikator ekspresi matematika ini siswa hanya menuliskan sebagian kecil informasi dari pernyataan ke dalam bahasa matematika.
\end{abstract}

Tabel 4. Hasil Indikator Ekspresi Matematika

\begin{tabular}{ccc}
\hline $\begin{array}{c}\text { Jumlah } \\
\text { Siswa }\end{array}$ & Persentase & Kriteria \\
\hline 0 & 0 & Sangat tinggi \\
\hline 2 & 8 & Tinggi \\
\hline 6 & 24 & Sedang \\
\hline 11 & 44 & Rendah \\
\hline 6 & 24 & Sangat rendah \\
\hline
\end{tabular}

\section{b. Menggambar Matematika (Indikator 2)}

Pada indikator ini siswa harus menyatakan suatu situasi dalam bentuk gambar atau grafik. Hasil tes kemampuan komunikasi matematis berdasarkan pada indikator ini ditunjukkan pada tabel 5 sebagai berikut: Tabel 5. Hasil Indikator Menggambar Matematika

\begin{tabular}{ccc}
\hline $\begin{array}{c}\text { Jumlah } \\
\text { Siswa }\end{array}$ & Persentase & Kriteria \\
\hline 9 & 36 & Sangat tinggi \\
\hline 0 & 0 & Tinggi \\
\hline 5 & 20 & Sedang \\
\hline 0 & 0 & Rendah \\
\hline 11 & 44 & Sangat rendah \\
\hline
\end{tabular}

Berdasarkan tabel 5 dapat dilihat tingkat kemampuan siswa pada indikator menggambar matematika, terdapat 9 siswa dengan kategori sangat tinggi, 0 siswa siswa dengan kategori tinggi, 5 siswa dengan kategori sedang, 0 siswa dengan kategori rendah, dan 11 siswa dengan kategori sangat rendah. Jadi dari 25 siswa tersebut ternyata tingkat kemampuan komunikasi matematis pada indikator menggambar matematika menyatakan siswa berkemampuan "sangat rendah" memiliki proporsi tertinggi sebanyak $44 \%$ berjumlah 11 siswa, kemudian diikuti siswa berkemampuan "sangat tinggi" sebanyak 36\% dengan jumlah 9 siswa, dilanjut dengan berkemampuan "sedang" sebanyak 20\% dengan jumlah 5 siswa, dan siswa berkamampuan "tinggi" dan "rendah" sebanyak 0\% dengan jumlah 0 siswa. Dapat disimpulkan bahwa siswa pada indikator menggambar matematika ini siswa hanya menghubungkan gambar ke dalam model matematika tetapi tidak mengarah pada jawaban yang benar atau salah.

\section{c. Pemahaman Matematika (Indikator 3)}

Pada indikator ini siswa harus Mampu menyatakan atau menjelaskan situasi dalam bentuk notasi atau simbol matematika atau model matematika. Hasil tes kemampuan komunikasi matematis berdasarkan pada indikator ini ditunjukkan pada tabel 6 sebagai berikut:

Tabel 6. Hasil Indikator Pemahaman Matematika

\begin{tabular}{ccc}
\hline Jumlah Siswa & Persentase & Kriteria \\
\hline 10 & 40 & Sangat tinggi \\
\hline 1 & 4 & Tinggi \\
\hline 1 & 4 & Sedang \\
\hline 4 & 16 & Rendah \\
\hline 9 & 36 & Sangat rendah \\
\hline
\end{tabular}

Berdasarkan tabel 6 dapat dilihat tingkat kemampuan siswa pada indikator pemahaman matematika, terdapat 10 siswa dengan kategori sangat tinggi, 1 siswa siswa dengan kategori tinggi, 1 siswa dengan kategori sedang, 4 siswa dengan kategori rendah, dan 9 siswa dengan kategori sangat rendah. Jadi dari 25 siswa tersebut ternyata tingkat kemampuan komunikasi matematis pada indikator pemahaman matematika menyatakan siswa berkemampuan "sangat tinggi" memiliki proporsi tertinggi sebanyak $40 \%$ berjumlah 10 siswa, kemudian diikuti siswa berkemampuan "sangat rendah" sebanyak 36\% dengan jumlah 9 siswa, dilanjut dengan berkemampuan "rendah" sebanyak 16\% dengan jumlah 4 siswa, dan siswa berkamampuan "tinggi" dan "sedang" sebanyak 4\% dengan jumlah 1 siswa. Dapat disimpulkan bahwa siswa pada indikator pemahaman matematika ini siswa dapat menyatakan masalah ke dalam simbol atau bahasa matematis dengan benar.

\section{PEMBAHASAN}

Dalam penelitian kualitatif ini bertujuan untuk mendekripsikan kemampuan komunikasi matematis siswa dengan mendasarkan salah satu tujuan utama dalam pembelajaran yakni melatih kemampuan komunikasi matematis siswa. Dalam proses pembelajaran matematika sebelumnya (melalui wawancara dengan guru) bahwa pembelajaran selalu berfokus pada guru serta proses pembelajaran cenderung satu arah, pembelajaran yang diberikan oleh guru kurang bermakna, pola pembelajaran guru bersifat rutinitas, pada saat mengajar matematika, guru langsung menjelaskan topik yang akan dipelajari.

Berdasarkan hasil analisis tingkat kemampuan komunkasi matematis siswa bahwa hasil tingkat berkemampuan "sangat tinggi" sebesar 16\% dengan jumlah siswa 4 orang, hasil tingkat berkemampuan "tinggi" sebesar 16\% dengan jumlah siswa 4 orang, hasil tingkat berkemampuan "sedang" sebesar 32\% dengan jumlah siswa 8 orang, hasil tingkat berkemampuan "rendah" sebesar $20 \%$ dengan jumlah siswa 5 orang, dan hasil tingkat berkemampuan "sangat rendah" sebesar $16 \%$ dengan jumlah siswa 4 orang. Pada hasil penelitian ini tingkat kemampuan komunikasi matematis siswa dikatakan sedang, berarti tingkat kemampuan komunikasi matematis siswa sudah mampu mengungkapkan atau menuliskan sebagian 
kecil informasi dan ide dari pernyataan ke dalam bahasa matematika, siswa sudah mampu sebagian kecil dapat menghubungkan gambar ke dalam model matematika, dan siswa sudah mampu sebagian kecil masalah ke dalam simbol atau bahasa matematis.

Hal ini didukung oleh hasil penelitian Werdiningsih, dkk (2019) menyatakan bahwa dari penelitian yang telah dilakukannya bahwa model komunikasi matematis siswa dengan kelompok sedang adalah siswa yang mampu menjelaskan ide dan situasi dalam bahasa tulis dengan tepat. Seorang siswa yang dapat mengungkapkan ide dan situasi menghadapi masalah ke dalam model matematika dengan tepat dan benar. Siswa yang tidak mampu menggunakan rumus untuk menghadapi masalah. Tetapi hal berbeda pada hasil penelitian Sriwahyuni, dkk (2019) menyatakan bahwa kemampuan komunikasi matematik pada siswa SMP pada materi Segiempat dan Segitiga masih termasuk kategori sangat rendah. Hal ini dapat dilihat dari hasil konversi skor kemampuan siswa kelas VIII D sebanyak 20 siswa berada dalam kategori sangat rendah dengan persentase $65 \%$, siswa kemampuan sedang 7 orang dengan persentase $23 \%$, siswa kemampuan rendah 3 orang dengan persentase $10 \%$, yang memiliki kemampuan tinggi hanya sebanyak 1 orang yaitu sebesar 3\%, dan siswa kemampuan sangat tinggi 0 orang dengan persentase $0 \%$.

\section{KESIMPULAN}

Berdasarkan hasil analisis dan pembahasan dan temuan selama pembelajaran dengan model TAPPS diperoleh beberapa kesimpulan yang merupakan jawaban atas pertanyaan-pertanyaan yang diajukan dalam rumusan masalah. Simpulan tersebut adalah sebagai berikut:

1. Siswa yang memiliki tingkat kemampuan komunikasi matematis pada siswa berkemampuan "sedang" memiliki proporsi tertinggi sebanyak $32 \%$, kemudian diikuti siswa berkemampuan "rendah" sebanyak 20\%, dan dilanjut dengan berkemampuan "sangat tinggi", "tinggi" dan "sangat rendah" masing-masing sebanyak $16 \%$.

2. Siswa yang memiliki kesulitan kemampuan komunikasi matematis siswa dalam pembelajaran model TAPPS, sebagai berikut:

a. Pada kategori sangat tinggi, siswa tidak mengalami kesulitan tetapi kurang teliti.

b. Pada kategori tinggi, siswa tidak mengalami kesulitan hanya saja siswa kurang teliti dan kurang lengkap dalam menuliskan informasi yang terdapat pada soal.

c. Pada kategori sedang, siswa kurang percaya dalam menyelasikan soal jadi mengalami sedikit kesulitan.

d. Pada kategori rendah, siswa kesulitan menuliskan dan susah mengungkapkan informai yang terdapat pada soal ke dalam bahasa sendiri, siswa kesulitan menghubungkan gambar ke dalam model matematika tetapi tidak mengarah pada jawaban yang benar atau salah dan siswa kesulitan memahami masalah yang terdapat di soal dan hanya bisa memasukkan sebagian kecil masalah ke dalam simbol atau bahasa matematis.

e. Pada kategori sangat rendah, siswa kesulitan mengerjakan soal dikarenakan soal-soal yang biasa mereka kerjakan soal rutin atau soal-soal yang begitu saja, sehingga mendapat soal yang berbeda mereka langsung tidak mampu atau menyamakan cara menegrjakan soalnya, siswa kesulitan membuat notasi matematika yang menghubungkan pada gambar dan siswa belum lancar memahami permasalahan ke dalam simbol matematika dengan baik sehingga saat menyelesaikan masalah tersebut siswa belum mampu mengikuti langkah-langkah metode penyelesaiannya sehingga penyelesaian masalah tidak tepat.

\section{UCAPAN TERIMA KASIH}

Ucapan terima kasih penulis haturkan kepada kepala sekolah SMP Wiraswasta Batang Kuis dan pihak-pihak sekolah yang telah mengizinkan saya melakukan penelitian di skeolah tersebut.

\section{REFERENSI}

Ansari, B.I. 2009. Komunikasi Matematika Konsep dan Aplikas. Pena Banda Aceh.

Depdiknas. 2006. Permendiknas No 22 Tahun 2006 Tentang Standar Isi. Jakarta : Depdiknas.

Kartono, and Sunarmi. 2015. Analisis Kemampuan Komunikasi Matematis Siswa Kelas VIII SMP Pada Model Pembelajaran TSTS Dengan Pendekatan Scientific. Unnes Journal of Mathematics Education. Semarang.

NCTM. 2000. Principles and Standards for School Mathematics. USA : NCTM.

Permendikbud No. 58 Tahun 2014 Tentang Pembelajaran Pada Pendidikan Dasar dan Pendidikan Menengah.

Sugiyono. 2016. Metode Penelitian Pendidikan Pendekatan Kuantitatif, kualitatif, dan $R \& D$. Bandung: Alfabeta

Suharno, Sulistiawati \& Arifin. 2019. Pengaruh Metode Thinking Aloud Pair Problem Solving (TAPPS) Terhadap Kemampuan Komunikasi Matematis Siswa Smp Negeri 1 Manggar. Jurnal Numeracy Vol.6, No.1

Sriwahyuni, Amelia \& Maya. 2019. Analisis Kemampuan Komunikasi Matematis Siswa Smp Pada Materi Segiempat Dan Segitiga. Jurnal Kajian Pembelajaran Matematika VOLUME 3 NOMOR 1. ISSN: $2549-8584$.

TIMSS. 2011. TIMSS 2011 Internasional Result In Mathematics. Chestnut Hill : TIMSS dan PIRLS Internasinoal Study Center. 